Article

\title{
Vermicompost Supplementation Improves the Stability of Bioactive Anthocyanin and Phenolic Compounds in Clinacanthus nutans Lindau
}

\author{
Zuhaili Yusof ${ }^{1}$, Sujatha Ramasamy ${ }^{1}$, Noor Zalina Mahmood ${ }^{1}$ (i) and \\ Jamilah Syafawati Yaacob ${ }^{1,2, *}$ \\ 1 Institute of Biological Sciences, Faculty of Science, University of Malaya, Kuala Lumpur 50603, Malaysia; \\ zuhailiyusof@yahoo.com (Z.Y.); sujatha@um.edu.my (S.R.); alin@um.edu.my (N.Z.M.) \\ 2 Centre for Research in Biotechnology for Agriculture (CEBAR), Institute of Biological Sciences, \\ Faculty of Science, University of Malaya, Kuala Lumpur 50603, Malaysia \\ * Correspondence: jamilahsyafawati@um.edu.my; Tel.: +60-3-7967-4090
}

Academic Editor: M. Monica Giusti

Received: 25 April 2018; Accepted: 30 May 2018; Published: 4 June 2018

\begin{abstract}
This project studied the effect of vermicompost application on the composition of bioactive anthocyanin and phenolic compounds, and the antioxidant activity of Clinacanthus nutans. The correlation between the bioactive constituents and antioxidant capacity was also evaluated. In this project, a field study was conducted using a randomized complete block design (RCBD) with four treatment groups, including control plants (CC), plants supplied with chemical fertilizer $(\mathrm{CF})$, plants supplied with vermicompost (VC), and plants supplied with mixed fertilizer (MF). The leaves of $C$. nutans from all treatment groups were harvested, subjected to solvent extraction, and used for quantification of total anthocyanin content (TAC), total phenolic content (TPC), and total flavonoid content (TFC). The initial antioxidant activity of the extracts was evaluated using 2,2-Diphenyl-1-picrylhydrazyl (DPPH) and 2,2'-azinobis(3-ethylbenzothiazoline-6-sulfonic acid) (ABTS) assays, as well as after two and four weeks of storage at $-20^{\circ} \mathrm{C}$ and $4{ }^{\circ} \mathrm{C}$. Data analysis showed that CC plants contained the highest TAC $(2180.14 \pm 338.43 \mu \mathrm{g} / \mathrm{g}$ dry weight $)$ and TFC $(276.25 \pm 3.09$ $\mathrm{mg}$ QE/g dry weight). On the other hand, CF plants showed the highest TPC (181.53 $\pm 35.58 \mathrm{mg}$ GAE/g dry weight). Moreover, we found that CC plants had the highest antioxidant potential against DPPH radicals whereas MF plants showed the lowest antioxidant potential. After four weeks of extract storage at $-20{ }^{\circ} \mathrm{C}$ and $4{ }^{\circ} \mathrm{C}$, the TPC, TFC, TAC, and antioxidant potential of the extracts decreased. Extracts from VC showed the lowest percentage of total phenolic and total flavonoid loss after extract storage at $-20{ }^{\circ} \mathrm{C}$ and $4{ }^{\circ} \mathrm{C}$ compared with other plant extracts. At this juncture, it could be deduced that the application of vermicompost had little effect on the expression of phenolics, flavonoids, or anthocyanin in C. nutans. However, the extract from plants treated with vermicompost (VC and MF) showed better stability compared with CC and CF after extract storage at different temperatures.
\end{abstract}

Keywords: total phenolic content; anthocyanin; flavonoid; antioxidant; extract storage; vermicompost; Clinacanthus nutans

\section{Introduction}

Clinacanthus nutans Lindau is an important medicinal plant from the family Acanthaceae. A tall, erect herbaceous perennial shrub, it grows up to one meter in height and is distributed throughout tropical regions, including Southeast Asia and China. The plant is locally known in Malaysia as "Belalai Gajah" due to the slightly curved stem supporting the leaves that resembles the curve of an 
elephant's trunk [1]. In Malaysia and Thailand, the leaves of C. nutans are used as a remedy against venomous snake bites, scorpion, and insect stings [2,3], resulting in the vernacular name, Sabah snake grass. C. nutans is classified as one of Malaysia's high-value herbal products in the Entry Point Project 1 (EPP1) in the agriculture sector, which is one of the identified National Key Economic Areas (NKEAs). C. nutans has been reported to contain various phytochemicals with biological activities including antioxidant [4,5], antimicrobial [6], anti-inflammatory [5,7], antivenom [2], and anticancer activities [3,8]. This plant has also been widely used for the treatment of various diseases such as cancer, herpes simplex virus (HSV), varicella-zoster virus (VZV) lesions, skin rashes, and kidney problems [1,3].

Researchers are increasingly embracing green technology and the usage of sustainable and environmentally friendly approaches to enhance the production of valuable secondary metabolites in plants. Plants produce essential secondary metabolites for their adaptation and defense against environmental stressors. For example, water-soluble flavonoids play an important role in protecting plant's cellular processes against ultraviolet-B (UVB) radiation [9]. Flavonoids are used in various industries, such as in the food industry as a food additive. In addition, flavonoids are used in the production of pharmaceutical products [10] and as a source of environmentally friendly colorants in the textile industry [11]. Among the pigments synthesized via the flavonoid pathway, anthocyanins are one of the most important. Anthocyanins can appear red, blue, or purple and have the potential to be a natural food colorant [12]. Anthocyanins have been reported to help in improving cardiovascular disease and cancer $[13,14]$. The vast benefits of anthocyanins have rendered them a healthier alternative to synthetic dyes and food colorants in the growing food and beverage industry, as the color property is seen as an important factor in influencing consumer acceptance and to reflect the quality of the product $[15,16]$. Moreover, advances in the use of natural dyes as functional colorants have been made in various sectors, such as in dye-sensitized solar cells, development of biomedical sensors, and optical data storage [17-20]. The applications of plant-derived natural colorants or dyes for green technology development appears to be limitless as demands for sustainable production of these valuable pigments continue to increase. Thus, "green" practices in the synthesis of these valuable pigments, such as through organic production, are key to increase consumer acceptance, especially for its application in the food industry.

In this study, the effects of organic growth supplements, including vermicompost in accumulation of bioactive phenolic, anthocyanin, and flavonoid compounds in C. nutans, as well as their antioxidant potential were evaluated. Vermicompost is an organic materials broken down by the interactions between microorganisms and earthworms in a mesophilic process to produce fully stabilized and organic soil amendments with low carbon to nitrogen $(\mathrm{C}: \mathrm{N})$ ratios [21]. Vermicompost is rich in NPK (nitrogen 2-3\%, phosphorus 1.55-2.25\%, and potassium 1.85-2.25\%), micronutrients, and beneficial soil microbes, so it is garnering attention as a greener replacement for chemical fertilizers to maintain and further improve soil quality. The application of vermicompost as an alternative to chemical fertilizer not only produces healthier plants, but it also increases plant resistance toward pests and diseases. Moreover, vermicomposting is a quicker and more cost-effective technique for composting as it helps in diverting organic waste from landfills. Vermicompost has been reported to significantly stimulate the growth of a wide range of plant species including several medicinal plants [22], horticultural crops [23-26], fruit crops [27,28], ornamentals [29,30], and forestry species [31-33]. However, few publications were found on the effect of vermicompost supplementation on the availability of phytoconstituents and bioactivity of C. nutans. Previous works conducted on the application of vermicompost only focused on the effects of its supplementation on plant growth. The outcomes of this study provide additional knowledge and understanding about the effects of vermicompost supplementation on the availability of bioactive phenolic and anthocyanin compounds in C. nutans. Thus, this study adds to the knowledge that can be used for ensuring sustainable production of these bioactive pigments from natural sources, while reducing the impact on the environment. 


\section{Materials and Methods}

\subsection{Sample Preparation}

In this project, a field study using a randomized complete block design (RCBD) with four treatment groups was conducted at Glami Lemi Biotechnology Research Centre (PPBGL), Jelebu, Malaysia. The treatment groups included control plants (CC), plants supplied with $10 \mathrm{t} /$ ha of NPK fertilizer (CF), plants supplied with vermicompost at $15 \mathrm{t} / \mathrm{ha}$ (VC), and plants supplied with mixed fertilizer (containing both $15 \mathrm{t}$ /ha of vermicompost and $5 \mathrm{t}$ /ha of NPK fertilizer; MF). All treatments were applied on the plots as a soil conditioner two weeks before the planting process. The leaves from three C. nutans plants of each of the three different blocks per treatment were harvested in February 2017, resulting in a total of nine samples for each treatment. C. nutans was identified by comparing the plant with a herbarium specimen and a voucher specimen (KLU 49509) was deposited at the Herbarium of Rimba Ilmu, Institute of Biological Sciences, University of Malaya, Kuala Lumpur, Malaysia. After harvesting the leaves, the methanolic extract of $C$. nutans was prepared, in which the fresh leaves were freeze-dried and subjected to solvent extraction using methanol. Briefly, $3 \mathrm{~g}$ of freeze-dried leaves were soaked in $90 \mathrm{~mL} \mathrm{70 \%} \mathrm{methanol} \mathrm{and} \mathrm{ground} \mathrm{using} \mathrm{a} \mathrm{mortar} \mathrm{and} \mathrm{pestle.} \mathrm{Then,}$ the sample mixture was incubated in solvent at $4{ }^{\circ} \mathrm{C}$ for $24 \mathrm{~h}$ followed by filtration using filter paper. The extraction process was repeated using the residue obtained from the filtration. The filtrates were pooled and evaporated to dryness using a rotary evaporator at $45^{\circ} \mathrm{C}$ to yield the methanolic extracts. The concentrated extract was adjusted to a concentration of $20 \mathrm{mg} / \mathrm{mL}$ using $70 \%$ methanol before it was stored at either $4{ }^{\circ} \mathrm{C}$ or $-20{ }^{\circ} \mathrm{C}$ until further analysis.

\subsection{Phytochemical Screening of Bioactive Compounds in C. nutans}

The presence of various phytochemicals such as alkaloid, tannin, phenol, flavonoid, and saponin in the samples was evaluated based on standard methods [34].

\subsubsection{Measurement of Total Anthocyanin Content}

The total anthocyanin content was determined using the $\mathrm{pH}$ differential method [35]. The methanolic extracts of $C$. nutans were diluted separately with two types of buffer: potassium chloride $(0.025 \mathrm{M})$ at $\mathrm{pH} 1.0$ and sodium acetate $(0.4 \mathrm{M})$ at $\mathrm{pH} 4.5$ using the ratio $1: 4$ (1 part test portion and 4 parts buffer). The absorbance was measured at wavelengths of $520 \mathrm{~nm}$ and $700 \mathrm{~nm}$ using UV-200-RS spectrophotometer (MRC Ltd., Holon, Israel). The concentration of anthocyanin pigment was measured using the following formula:

$$
\begin{gathered}
\text { Anthocyanin pigment content }(\mathrm{mg} / \mathrm{L})=\frac{(\mathrm{A} \times \mathrm{MW} \times \mathrm{DF} \times 1000)}{(\varepsilon \times 1)} \\
\text { where } \mathrm{A}=\left(\mathrm{Abs}_{520}-\mathrm{Abs}_{700}\right) \mathrm{pH} 1.0-\left(\mathrm{Abs}_{520}-\mathrm{Abs}_{700}\right) \mathrm{pH} 4.5 \\
\mathrm{MW}(\text { cyanidin }-3-\text { glucoside })=449.2 \mathrm{~g} / \mathrm{mol} \\
\mathrm{DF}=\text { dilution factor } \\
\varepsilon=26,900
\end{gathered}
$$

\subsubsection{Measurement of Total Phenolic Content}

Folin-Ciocalteu's method was used to quantify the total phenolic content of C. nutans according to the method described by Sun, etal. [36] with minor changes. Briefly, Folin-Ciocalteu reagent was diluted 10-fold with deionised water. A total of $0.1 \mathrm{~mL}$ of $C$. nutans methanolic extract was mixed with $0.75 \mathrm{~mL}$ of diluted Folin-Ciocalteu reagent and incubated for $10 \mathrm{~min}$ at room temperature. Then, $0.75 \mathrm{~mL}$ of $2 \%$ sodium carbonate $\left(\mathrm{Na}_{2} \mathrm{CO}_{3}\right)$ solution was added. The mixture was allowed to stand in the dark for $45 \mathrm{~min}$ before measuring the absorbance at $765 \mathrm{~nm}$ using a UV-200-RS spectrophotometer 
(MRC Ltd., Holon, Israel) against a blank, containing the solvent (70\% methanol). The TPC of the samples was determined from a calibration curve prepared with a series of gallic acid standards $(0.01$, $0.02,0.03,0.04,0.05$, and $0.06 \mathrm{mg} / \mathrm{mL}$ ). Results were expressed as $\mathrm{mg}$ of gallic acid equivalents $/ \mathrm{g}$ dry weight (mg GAE/g DW) of extract.

\subsubsection{Measurement of Total Flavonoid Content}

The aluminum chloride colorimetric method [37] was used to quantify the total flavonoid content in the methanolic extracts of $C$. nutans. First, $0.5 \mathrm{~mL}$ of each extract was mixed with $1.5 \mathrm{~mL}$ of $70 \%$ methanol, $0.10 \mathrm{~mL}$ of $10 \%$ aluminum chloride, $\mathrm{AlCl}_{3}\left(\mathrm{AlCl}_{3} \cdot 6 \mathrm{H}_{2} \mathrm{O}\right), 0.10 \mathrm{~mL}$ of sodium acetate $\left(\mathrm{NaC}_{2} \mathrm{H}_{3} \mathrm{O}_{2} \cdot 3 \mathrm{H}_{2} \mathrm{O}\right)(1 \mathrm{M})$, and $2.80 \mathrm{~mL}$ of distilled water. Then, the absorbance was measured at $415 \mathrm{~nm}$ using a UV-200-RS spectrophotometer (MRC Ltd., Holon, Israel) after 40 min of incubation. The flavonoid concentrations were calculated by preparing a calibration curve using quercetin as the standard (0.15-0.4 mg/mL). The flavonoid concentration was expressed as quercetin equivalents in mg per gram of dry weight (mg/g DW) of extract. All assays were performed in triplicate.

\subsection{DPPH (2,2-Diphenyl-1-picrylhydrazyl) Radical Scavenging Activity Assay}

DPPH free radical scavenging activity of the C. nutans methanolic extracts was analyzed following standard procedure [38]. First, $50 \mu \mathrm{L}$ of extract at six different concentrations $(0.5,1.0,1.5,2.0,2.5$, and $3.0 \mathrm{mg} / \mathrm{mL})$ were added to $150 \mu \mathrm{L}$ of DPPH solution $(60 \mathrm{mM})$ in each well of a $96-$ well plate. The mixture was then incubated at room temperature for $30 \mathrm{~min}$. Then, $50 \mu \mathrm{L}$ of methanol was added to the DPPH solution as a blank. At the end of the incubation period, a Multiskan Go plate reader (Thermo Scientific, Waltham, MA, USA) was used to measure the absorbance at $515 \mathrm{~nm}$. All the extracts were assayed in triplicate. The obtained data were then used to determine the concentration of the sample required to scavenge $50 \%$ of the $\mathrm{DPPH}$ free radicals $\left(\mathrm{IC}_{50}\right)$. The percentage of inhibition was plotted against the concentration and the $\mathrm{IC}_{50}$ was obtained from the fitted linear curve. A lower $\mathrm{IC}_{50}$ denotes a more potent antioxidant.

\subsection{ABTS (2,2'-Azinobis(3-ethylbenzothiazoline-6-sulfonic acid)) Radical Scavenging Activity Assay}

The colorimetric method described by Shao et al. [39] was used to perform the ABTS scavenging activity assay, with slight modifications. First, the preparation of the ABTS radical cation was performed by mixing $10 \mathrm{~mL}$ of $2.6 \mathrm{mM} \mathrm{K}_{2} \mathrm{~S}_{2} \mathrm{O}_{4}$ solution with $10 \mathrm{~mL}$ of $7.4 \mathrm{mM}$ ABTS solution. Then, the mixture was stored for $12 \mathrm{~h}$ at room temperature in a dark room before further use. After that, double distilled water $\left(\mathrm{ddH}_{2} \mathrm{O}\right)$ was used to dilute the mixture and it was adjusted to produce an absorbance reading of $0.70 \pm 0.2$ at $734 \mathrm{~nm}$. A $20 \mu \mathrm{L}$ of sample at six different concentrations $(0.5,1$, $1.5,2.0,2.5$, and $3.0 \mathrm{mg} / \mathrm{mL}$ ) was then added to $200 \mu \mathrm{L}$ ABTS solution and the mixture was incubated at room temperature for $30 \mathrm{~min}$. The absorbance reading was measured at $734 \mathrm{~nm}$ using a Multiskan Go plate reader (Thermo Scientific, Waltham, MA, USA) and the assay was performed in triplicate. The percentage of inhibition was calculated according to the following formula:

$$
\% \text { inhibition }=\frac{\left(\mathrm{Abs}_{\text {blank }}-\mathrm{Abs}_{\text {sample }}\right)}{\left(\mathrm{Abs}_{\text {blank }}\right)} \times 100
$$

The antioxidant capacity of the test extracts is expressed as $\mathrm{IC}_{50}$, which is the concentration necessary for a $50 \%$ reduction in ABTS radicals.

\subsection{Extract Stability after Storage at Different Temperatures}

In this study, the effect of the growth supplements on the stability of the methanolic extracts following extract storage at different temperatures was analyzed. For this, the extracts were stored at $4{ }^{\circ} \mathrm{C}$ or $-20^{\circ} \mathrm{C}$ for 2 and 4 weeks and then used in the determination of phenolic, anthocyanin and flavonoid contents. The effect of extract storage on antioxidant properties of the extracts was also determined. 


\subsection{Statistical Analysis}

The data obtained in this study were subjected to statistical analysis using analysis of variance (ANOVA) and the mean values were compared using Duncan's Multiple Range Test (DMRT) in SPSS software version 24. Pearson correlation analysis was also conducted to determine the relationship between the antioxidant potential with the amount of bioactive phenolic, anthocyanin, and flavonoid present in the extracts.

\section{Results and Discussion}

\subsection{Phytochemical Screening}

Qualitative screening of C. nutans methanolic extract was performed using standard protocols [34]. Results of the present study revealed the presence of phenols, flavonoid, and saponin in the methanolic extracts of $C$. nutans leaves (Table 1 ) but were negative for alkaloid and tannin (Table 1). These results are in agreement with previous studies $[25,40]$. However, the methanolic extract of $C$. nutans has also been reported to contain steroids and triterpenes [40].

Table 1. Effect of plant growth supplements on availability of phytoconstituents in methanolic extracts of Clinacanthus nutans leaves.

\begin{tabular}{ccccc}
\hline \multirow{2}{*}{ Phytochemical } & \multicolumn{4}{c}{ Treatment } \\
\cline { 2 - 5 } & No Fertilizer (CC) & NPK Fertilizer (CF) & Vermicompost (VC) & Mixed Fertilizer (MF) \\
\hline Alkaloid & - & - & - & - \\
Tannin & - & - & - & - \\
Phenol & + & + & + & + \\
Flavonoid & + & + & + & + \\
Saponin & + & + & + & + \\
\hline \multicolumn{5}{c}{}
\end{tabular}

\subsection{Determination of Pigments Content (Total Anthocyanin, Phenolic and Flavonoid)}

The total anthocyanin (TAC), total phenolic (TPC), and total flavonoid (TFC) contents in the methanolic extracts of $C$. nutans were measured. The TPC was expressed as mg gallic acid (GAE) per $g$ dry weight of the sample, whereas the TFC was expressed as mg quercetin (QE) per g dry weight of the sample. Based on Table 2, the highest TAC was obtained in CC plants $(2180.14 \pm 338.43 \mu \mathrm{g} / \mathrm{g}$ dry weight), followed by CF, VC, and MF (Table 2). However, data analysis revealed that the differences observed among the TAC of all samples were not statistically significant. Conversely, significantly higher TFC was found in the methanolic extracts of CC (276.25 $\pm 3.09 \mathrm{mg}$ QE/g dry weight) and CF (256.66 $\pm 45.43 \mathrm{mg} \mathrm{QE} / \mathrm{g}$ dry weight) plants, compared with VC and MF. CF plant extract was also observed to contain the highest TPC (181.53 $\pm 35.58 \mathrm{mg}$ GAE/g dry weight), followed by CC, VC, and MF (Table 2).

Table 2. Effect of plant growth supplementation on total phenolic, anthocyanin, and flavonoid contents in methanolic extracts of $C$. nutans leaves.

\begin{tabular}{ccccc}
\hline Treatment & Sample ID & $\begin{array}{c}\text { Total Anthocyanin } \\
\text { Content } \\
(\mu \mathbf{g} / \mathbf{g} \text { DW) }\end{array}$ & $\begin{array}{c}\text { Total Phenolic } \\
\text { Content } \\
(\mathbf{m g} \text { GAE/g DW) }\end{array}$ & $\begin{array}{c}\text { Total Flavonoid } \\
\text { Content } \\
(\mathbf{m g} \text { QE/g DW) }\end{array}$ \\
\hline No fertilizer & CC & $2180.14 \pm 338.43^{\mathrm{a}}$ & $120.48 \pm 6.70^{\mathrm{a}}$ & $276.25 \pm 3.09^{\mathrm{b}}$ \\
NPK fertilizer & CF & $1933.52 \pm 66.06^{\mathrm{a}}$ & $181.53 \pm 35.58^{\mathrm{b}}$ & $256.66 \pm 45.43^{\mathrm{b}}$ \\
Vermicompost & VC & $1742.86 \pm 62.30^{\mathrm{a}}$ & $98.06 \pm 2.27^{\mathrm{a}}$ & $170.42 \pm 7.55^{\mathrm{a}}$ \\
Mixed fertilizer & MF & $1669.91 \pm 122.12^{\mathrm{a}}$ & $97.47 \pm 18.73^{\mathrm{a}}$ & $157.30 \pm 26.42^{\mathrm{a}}$ \\
\hline
\end{tabular}

Note: Means with different letters within the same column are significantly different at $p \leq 0.05$ according to Duncan's multiple range test (DMRT). 


\subsection{Antioxidant Potential of C. Nutans Methanolic Extracts against DPPH and ABTS Radicals}

The DPPH assay is typically based on the scavenging of free radicals and converting them to colorless products. When the methanolic extract of $C$. nutans reacts with DPPH solution, the free radicals are reduced by hydrogen donation to produce the reduced form of 1,1-diphenyl-2-picryl hydrazine (non-radical), indicated by the color change from violet to pale yellow [41]. The ABTS (2,2'-azinobis(3-ethylbenzothiazoline-6-sulfonic acid)) assay is a decolourization assay in which the stable radical is generated directly through the reaction of ABTS with potassium persulfate, which resulted in the production of blue or green ABTS chromophore, prior to reaction with the antioxidants. The free radical scavenging activity of the extracts against DPPH and ABTS is expressed as $\mathrm{IC}_{50}$ (mg per $\mathrm{mL}$ of extract), which is the concentration of antioxidant necessary to decrease the initial DPPH and ABTS concentration by $50 \%$. The antioxidant activities of the extracts against both DPPH and ABTS radicals are displayed in Table 3. Data analysis revealed that the methanolic extract from control plants (CC) exhibited the highest free radical scavenging activity against DPPH and ABTS radicals, with an $\mathrm{IC}_{50}$ of $1.18 \pm 0.05 \mathrm{mg} / \mathrm{mL}$ and $0.98 \pm 0.05 \mathrm{mg} / \mathrm{mL}$, respectively (Table 3). The antioxidant activity (denoted by $\mathrm{IC}_{50}$ ) of the methanolic extracts against both DPPH and ABTS radicals, in decreasing order, is $\mathrm{CC}, \mathrm{CF}, \mathrm{VC}$, and $\mathrm{MF}$.

Table 3. Effect of plant growth supplements on antioxidant potential of methanolic extracts of $C$. nutans leaves.

\begin{tabular}{cccc}
\hline Treatment & Sample ID & DPPH IC $_{\mathbf{5 0}}(\mathbf{m g} / \mathbf{m L})$ & ABTS IC $_{50}(\mathbf{m g} / \mathbf{m L})$ \\
\hline No fertilizer & CC & $1.18 \pm 0.05^{\mathrm{a}}$ & $0.98 \pm 0.05^{\mathrm{a}}$ \\
NPK fertilizer & CF & $1.41 \pm 0.02^{\mathrm{b}}$ & $1.15 \pm 0.16^{\mathrm{a}} \mathrm{b}$ \\
Vermicompost & VC & $1.67 \pm 0.04^{\mathrm{c}}$ & $1.41 \pm 0.01^{\mathrm{b}, \mathrm{c}}$ \\
Mixed fertilizer & MF & $2.23 \pm 0.02^{\mathrm{d}}$ & $1.67 \pm 0.17^{\mathrm{c}}$ \\
\hline
\end{tabular}

Note: Means with different letters within the same column are significantly different at $p \leq 0.05$ according to Duncan's multiple range test (DMRT).

Based on the results of the present study, the antioxidant capacity of the methanolic extracts of C. nutans evaluated by the ABTS method was higher than that evaluated with the DPPH method. The DPPH assay underestimated the antioxidant capacity of the methanolic extracts of $C$. nutans by $18.44-33.53 \%$ compared to the ABTS assay. This observation is in agreement with a previous study by Almeida et al. [42] that showed that a higher antioxidant capacity was obtained for fresh Brazilian exotic fruits when evaluated by ABTS assay compared with evaluation using the DPPH method. This observation can be attributed to several factors, such as the wavelengths used during the spectrophotometric measurement in both assays, where $515 \mathrm{~nm}$ was used in DPPH assays and $734 \mathrm{~nm}$ was used in ABTS assays. Arnao [43] reported that the underestimation by DPPH assays could be due to the pigments contained in the colored extracts (such as carotenoids and anthocyanins) having overlapping absorbance spectra in the visible region with that of DPPH at $515 \mathrm{~nm}$, thus interfering with the absorbance readings.

This underestimate could be due to the structural conformation of the antioxidants that influenced the reaction mechanism of free radical scavengers and DPPH. Larger molecules that have less access to the radical site have a lower antioxidant activity for a particular test compared with smaller molecules [44]. Otherwise, the underestimation could be due to the reactions of certain phenols such as eugenol and its derivatives that are reversible when reacted with DPPH, resulting in low readings of the antioxidant capacity [45]. However, DPPH assays also have an advantage over ABTS assays, as the DPPH free radicals can be directly acquired without preparation so they are ready to dissolve, whereas ABTS radical cations must be produced through enzymatic (peroxidase and myoglobin) or chemical (manganese dioxide and potassium persulfate) reactions [43]. Nevertheless, both the ABTS and DPPH assays have been the most popular spectrophotometric methods for determination of antioxidant capacity of foods and chemical compounds [46]. 
3.4. Effect of C. Nutans Extracts Storage (Duration and Temperature) on Stability of Pigments and Antioxidant Activity

In this study, the TPC, TAC, and TFC of the methanolic extracts after two and four weeks of storage at $-20{ }^{\circ} \mathrm{C}$ and $4{ }^{\circ} \mathrm{C}$ were also evaluated. As shown in Figure 1, the TAC of all plant extracts decreased after four weeks of storage at $-20{ }^{\circ} \mathrm{C}$ and $4{ }^{\circ} \mathrm{C}$. More than $50 \%$ of the total anthocyanin loss for CC and CF plant extracts occurred after four weeks of storage at $-20^{\circ} \mathrm{C}$ and $4{ }^{\circ} \mathrm{C}$ compared to VC and MF. VC plant extract showed the lowest percentage of total anthocyanin loss (21.0\%) after four weeks of storage at $4{ }^{\circ} \mathrm{C}$, compared to other extracts that exhibited a TAC loss of more than $50 \%$.
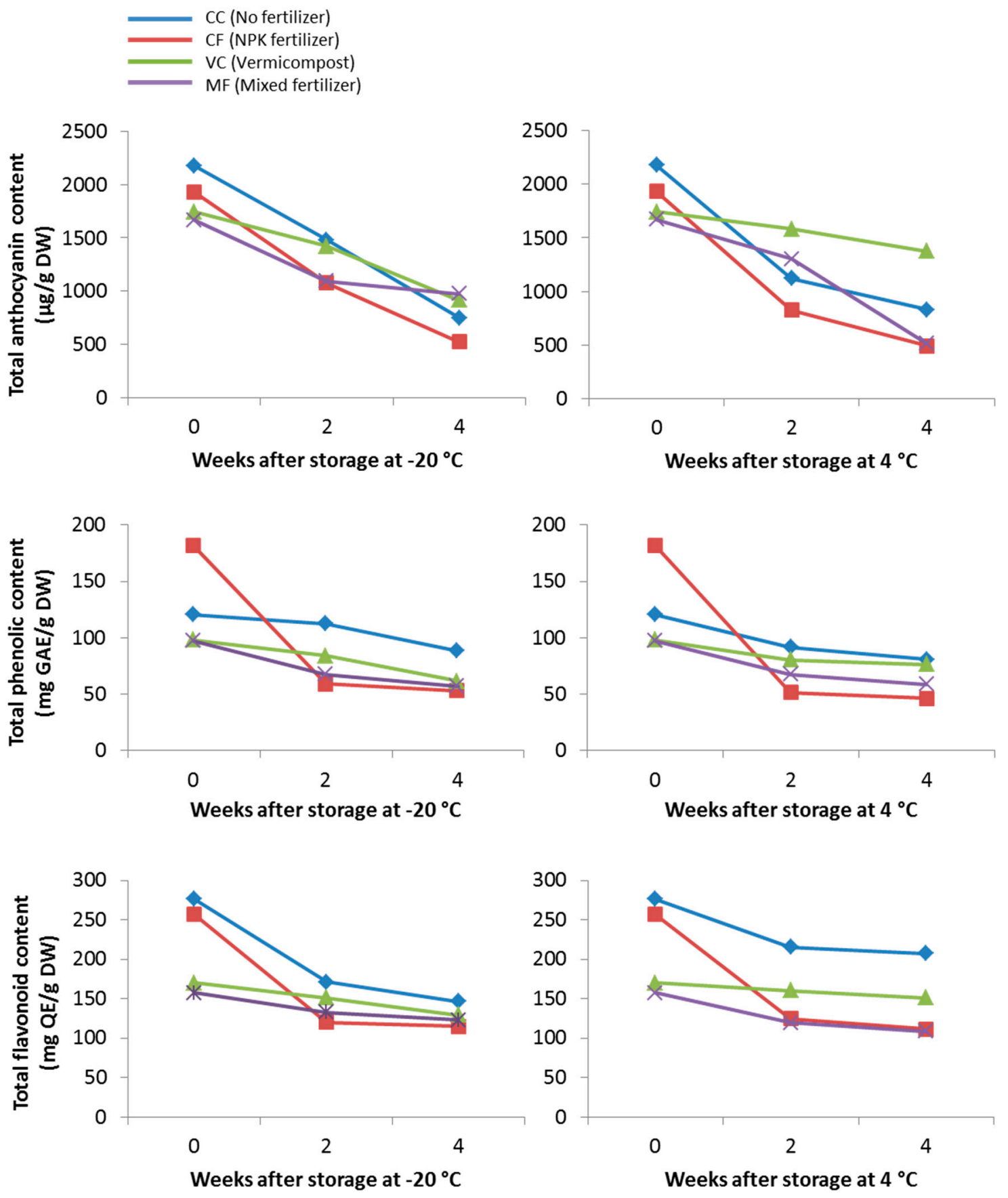

Figure 1. Effect of extract storage at $-20{ }^{\circ} \mathrm{C}$ and $4{ }^{\circ} \mathrm{C}$ on total anthocyanin (TAC), total phenolic (TPC), and total flavonoid (TFC) contents in the methanolic extracts of $C$. nutans supplemented with different fertilizers. 
Data analysis showed that TPC of the extracts decreased gradually with extract storage (Figure 1). After 4 weeks of storage at $-20{ }^{\circ} \mathrm{C}$, the TPC was observed to decrease by $26.62 \%, 70.75 \%, 37.04 \%$ and $41.19 \%$ for CC, CF, VC, and MF extracts, respectively. Plants supplemented with vermicompost (VC) showed the least percentage of TPC loss after extract storage at $4{ }^{\circ} \mathrm{C}$, compared to other plant extracts (Figure 1). It was also observed that plants supplemented with only NPK fertilizer (CF) showed the highest TPC loss after extract storage at both $-20^{\circ} \mathrm{C}$ and $4{ }^{\circ} \mathrm{C}$ (Figure 1). Similar results were observed for TFC, where CF plant extracts were found to exhibit the highest TFC loss after extract storage (Figure 1). Interestingly, data analysis again revealed that plants supplemented with vermicompost (VC) exhibited the lowest percentage of TFC loss, with a decrease of $23.96 \%$ and $11.30 \%$ after 4 weeks of storage at $-20^{\circ} \mathrm{C}$ and $4{ }^{\circ} \mathrm{C}$, respectively.

Furthermore, the antioxidant potential of the plant extracts following extract storage at $-20{ }^{\circ} \mathrm{C}$ and $4{ }^{\circ} \mathrm{C}$ were also monitored. Data analysis revealed that after 4 weeks of storage, the antioxidant potential of the extracts was significantly reduced, as denoted by the increase in $\mathrm{IC}_{50}$ values. As observed in Figure 2, plant extracts from CF showed the highest loss of antioxidant potential against DPPH and ABTS radicals, when stored at both $-20{ }^{\circ} \mathrm{C}$ and $4{ }^{\circ} \mathrm{C}$. It was also evident that supplementation with vermicompost (VC and MF) improved the stability of antioxidants present in the extracts (Figure 2). Based on correlation analysis (Table 4), the antioxidant potential exhibited by the plant extracts could be due to their pigments content (anthocyanin, phenolic and flavonoid), as shown by the negative correlations observed. The significant negative correlations indicate that the DPPH and ABTS IC F0 $_{50}$ values decreased with increasing anthocyanin, phenolic and flavonoid content. However, these correlations were only moderate, except for TAC, which was shown to be strongly correlated with DPPH IC $\mathrm{C}_{50}$.
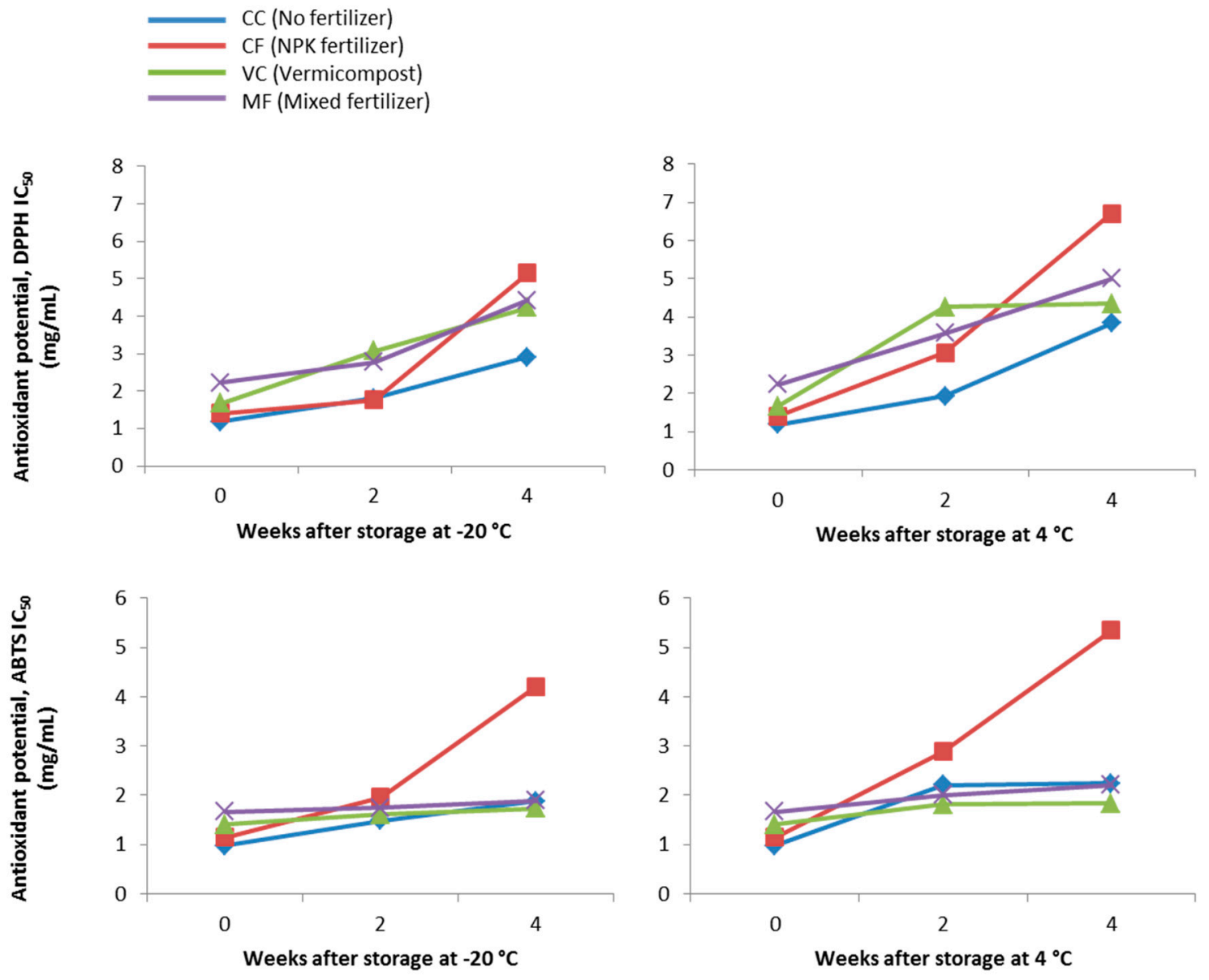

Figure 2. Effect of extract storage at $-20^{\circ} \mathrm{C}$ and $4{ }^{\circ} \mathrm{C}$ on antioxidant potential of the methanolic extracts of Clinacanthus nutans supplemented with different fertilizers. 
Table 4. Pearson's correlation coefficients between the variables.

\begin{tabular}{cccccc}
\hline Variables & TFC & TPC & TAC & DPPH & ABTS \\
\hline TFC & 1 & & & \\
TPC & $0.834^{* *}$ & 1 & 1 & & \\
TAC & $0.399^{* *}$ & $0.429^{* *}$ & 1 & 1 & \\
DPPH & $-0.465^{* *}$ & $-0.464^{* *}$ & $-0.518^{* *}$ & 1 \\
ABTS & $-0.376^{* *}$ & $-0.401^{* *}$ & $-0.427^{* *}$ & $0.545^{* *}$ & 1 \\
\hline \multicolumn{6}{c}{ Correlation is significant at $p<0.01}$.
\end{tabular}

Based on the results obtained, vermicompost does not exert any significant effect on the expression of bioactive compounds, as evident by the lower values (TAC, TPC, and TFC) obtained for all vermicompost-treated plants. This finding is in agreement with a previous study conducted on lettuce (Lactuca sativa L.), which showed that vermicompost fertilization significantly increased the crop yield, but reduced the levels of phenolic compounds and antioxidant activity [47]. Similarly, pak choi (Brassica rapa cv Bonsai, Chinensis group) and chincuya (Annona purpurea Moc and Sesse ex Dunal) plants grown with vermicompost were also reported to contain lower amounts of phenolic compounds [48,49]. These observations indicate that some factors may be present in vermicompost that negatively interferes with the synthesis of phenolic compounds through the phenylpropanoid pathway [47]. The accumulation of these various secondary metabolites has been shown to be affected by the interactions between plant genotype (species and variety within species) and environmental factors, including cultivation technique, season, abiotic and biotic stresses, and nutrient status [50,51]. The nutritional status of plants plays an important role in supporting plant growth, and various studies have demonstrated that supplementation of vermicompost provides nutrients to the plants in readily available forms such as nitrogen and enhances plant nutrient-uptake [52]. Thus, the production of the resulting phenolics and flavonoids are low when plants are not nutrient-limited.

The degradation of the compounds following extract storage that was observed in this study was consistent with previous findings [53], where the total phenolic content in Cornelian cherries extracts was found to decrease after being stored at $2{ }^{\circ} \mathrm{C}$ for up to 60 days. A drastic decrease was observed in the total phenolic and flavonoid content of Anemopsis californica extracts after being stored at $4{ }^{\circ} \mathrm{C}$ [54]. The decrease in total phenolics and flavonoids after prolonged storage was caused by various factors including oxidation by enzymes such as glycosidase, phenolase, and polyphenol oxidase (PPO), degradation of compounds, the polymerization of these compounds with proteins, and the conversion between free and bound phenolic substances [55-57]. PPO is an enzyme that causes the oxidation of phenolic compounds to quinones [58] by using polyphenols as the substrate [59]. Additionally, sample processing could cause disruption of the cell structure, which results in the loss of total phenolics and flavonoids [60]. Conversely, the decrease in total phenolic content may be due to non-enzymatic reactions that can contribute to the loss of total phenolic and flavonoid contents after storage. For example, the hydrogen peroxide produced as the by-product from the oxidation of ascorbic acid to dehydroascorbic acid can adversely affect the production of phenolic compounds [61], and the production of ascorbic acid and dehydroascorbic acid has been reported to increase due to chilling stress [62].

Results of the current study indicate that organic fertilization through supplementation with vermicompost contributed to the stability of the bioactive compounds during storage. At present, no published scientific literature was found on the exact mechanisms behind this observation. However, we postulate that the chemical compounds present in the plants supplemented with vermicompost (VC and MF) may undergo less oxidation, less degradation, and less polymerization compared with the compounds present in plants supplemented with chemical fertilizer (CF) and control plants (CC). Moreover, soil and fertilizer application has been found to affect protein composition and concentration in plants [63], which can interact with plant polyphenols. Various scientific literature has reported that the covalent interaction between plant polyphenols and proteins can further influence the content of 
free polyphenols and their antioxidant capacity during processing, transportation, and storage [64-66]. This implies that further studies involving multi-omics platforms, such as through metabolomics and proteomics, are essential for better understanding of the dynamics of protein and compound synthesis in relation to fertilization practices, as well as their interactions.

\section{Conclusions}

Vermicompost does not exert any significant effect on the plant antioxidant activity and the composition of bioactive compounds. However, the usage of vermicompost produced plants with the same content of bioactive compounds as the control and as the plants supplied with chemical fertilizer. Different storage conditions affected the stability of the bioactive compounds present in the methanolic extracts; however, plants supplemented with vermicompost were found to exhibit better stability when stored at different storage conditions.

Author Contributions: N.Z.M. and J.S.Y. conceived and designed the experiments; Z.Y. performed the experiments; Z.Y., S.R. and J.S.Y. analyzed the data; S.R., N.Z.M. and J.S.Y. contributed reagents/materials/analysis tools; Z.Y., S.R. and J.S.Y. wrote the paper.

Funding: This research was funded by University of Malaya, Malaysia (grant number RP022A-16SUS, RP015B-14AFR and CEBAR RU006-2017).

Acknowledgments: The authors thank the University of Malaya, Malaysia for experimental facilities and financial support (Grant No. RP022A-16SUS, RP015B-14AFR and CEBAR RU006-2017) provided.

Conflicts of Interest: The authors declare no conflict of interest.

\section{References}

1. Zakaria, Z.A.; Rahim, M.H.A.; Mohtarrudin, N.; Kadir, A.A.; Cheema, M.S.; Ahmad, Z.; Mooi, C.S.; Tohid, S.F.M. Acute and sub-chronic oral toxicity studies of methanol extract of Clinacanthus nutans in mice. Afr. J. Tradit. Complement. Altern. Med. 2016, 13, 210-222. [CrossRef]

2. Uawonggul, N.; Chaveerach, A.; Thammasirirak, S.; Arkaravichien, T.; Chuachan, C.; Daduang, S. Screening of plants acting against Heterometrus laoticus scorpion venom activity on fibroblast cell lysis. J. Ethnopharmacol. 2006, 103, 201-207. [CrossRef] [PubMed]

3. Kamarudin, M.N.A.; Sarker, M.M.R.; Kadir, H.A.; Ming, L.C. Ethnopharmacological uses, phytochemistry, biological activities, and therapeutic applications of Clinacanthus nutans (Burm. f.) Lindau: A comprehensive review. J. Ethnopharmacol. 2017, 206, 245-266. [CrossRef] [PubMed]

4. Yong, Y.K.; Tan, J.J.; Teh, S.S.; Mah, S.H.; Ee, G.C.L.; Chiong, H.S.; Ahmad, Z. Clinacanthus nutans extracts are antioxidant with antiproliferative effect on cultured human cancer cell lines. Evid.-Based Complement. Altern. Med. 2013, 2013, 462751. [CrossRef] [PubMed]

5. Alam, A.; Ferdosh, S.; Ghafoor, K.; Hakim, A.; Juraimi, A.S.; Khatib, A.; Sarker, Z.I. Clinacanthus nutans: A review of the medicinal uses, pharmacology and phytochemistry. Asian Pac. J. Trop. Med. 2016, 9, 402-409. [CrossRef] [PubMed]

6. Arullappan, S.; Rajamanickam, P.; Thevar, N.; Kodimani, C.C. In vitro screening of cytotoxic, antimicrobial and antioxidant activities of Clinacanthus nutans (Acanthaceae) leaf extracts. Trop. J. Pharm. Res. 2014, 13, 1455-1461. [CrossRef]

7. Wanikiat, P.; Panthong, A.; Sujayanon, P.; Yoosook, C.; Rossi, A.G.; Reutrakul, V. The anti-inflammatory effects and the inhibition of neutrophil responsiveness by Barleria lupulina and Clinacanthus nutans extracts. J. Ethnopharmacol. 2008, 116, 234-244. [CrossRef] [PubMed]

8. Farooqui, M.; Hassali, M.A.; Shatar, A.K.A.; Farooqui, M.A.; Saleem, F.; ul Haq, N.; Othman, C.N. Use of complementary and alternative medicines among Malaysian cancer patients: A descriptive study. J. Tradit. Complement. Med. 2016, 6, 321-326. [CrossRef] [PubMed]

9. Jordan, B.R. Plant pigments and protection against UV-B radiation. In Plant Pigments Their Manipulation; Blackwell: Oxford, UK, 2004; pp. 275-292.

10. Azmir, J.; Zaidul, I.; Rahman, M.; Sharif, K.; Mohamed, A.; Sahena, F.; Jahurul, M.; Ghafoor, K.; Norulaini, N.; Omar, A. Techniques for extraction of bioactive compounds from plant materials: A review. J. Food Eng. 2013, 117, 426-436. [CrossRef] 
11. Gürses, A.; Açıkyıldız, M.; Güneş, K.; Gürses, M.S. Colorants in Health and Environmental Aspects. In Dyes and Pigments; Springer International Publishing: Cham, Switzerland, 2016; pp. 69-83.

12. Khoo, H.E.; Azlan, A.; Tang, S.T.; Lim, S.M. Anthocyanidins and anthocyanins: Colored pigments as food, pharmaceutical ingredients, and the potential health benefits. Food Nutr. Res. 2017, 61, 1361779. [CrossRef] [PubMed]

13. Ananga, A.; Georgiev, V.; Ochieng, J.; Phills, B.; Tsolova, V. Production of anthocyanins in grape cell cultures: A potential source of raw material for pharmaceutical, food, and cosmetic industries. In The Mediterranean Genetic Code-Grapevine and Olive; In Tech: Vienna, Austria, 2013.

14. Jacobo-Herrera, N.J.; Jacobo-Herrera, F.E.; Zentella-Dehesa, A.; Andrade-Cetto, A.; Heinrich, M.; Pérez-Plasencia, C. Medicinal plants used in Mexican traditional medicine for the treatment of colorectal cancer. J. Ethnopharmacol. 2016, 179, 391-402. [CrossRef] [PubMed]

15. Giusti, M.M.; Wallace, T.C. Flavonoids as Natural Pigments. In Handbook of Natural Colorants; John Wiley \& Sons, Ltd.: Chichester, UK, 2009; pp. 255-275.

16. Mateus, N.; de Freitas, V. Anthocyanins as Food Colorants. In Anthocyanins: Biosynthesis, Functions, and Applications; Winefield, C., Davies, K., Gould, K., Eds.; Springer: New York, NY, USA, 2009; pp. 284-304.

17. Kim, S.H. Functional Dyes; Elsevier Science: Amsterdam, The Netherlands, 2006.

18. Ayalew, W.A.; Ayele, D.W. Dye-sensitized solar cells using natural dye as light-harvesting materials extracted from Acanthus sennii chiovenda flower and Euphorbia cotinifolia leaf. J. Sci. Adv. Mater. Devices 2016, 1, 488-494. [CrossRef]

19. Mustroph, H.; Stollenwerk, M.; Bressau, V. Current Developments in Optical Data Storage with Organic Dyes. Angew. Chem. Int. Ed. 2006, 45, 2016-2035. [CrossRef] [PubMed]

20. El-Shishtawy, R.M. Functional Dyes, and Some Hi-Tech Applications. Int. J. Photoenergy 2009, $2009,434897$. [CrossRef]

21. Ramasamy, P.K.; Suresh, S.N. Effect of vermicompost on root numbers and length of sunflower plant (Helianthus annuus L.). J. Pure Appl. Microbiol. 2010, 4, 297-302.

22. Chiluvuru, N.; Tartte, V.; Kalla, C.M.; Kommalapati, R. Plant bioassay for assessing the effects of vermicompost on growth and yield of Vigna radiata and Centella asiatica, two important medicinal plants. J. Dev. Sustain. Agric. 2009, 4, 160-164.

23. Sundararasu, K.; Neelanarayanan, P. Effect of vermicompost and inorganic fertilizer on the growth and yield of tomato, Lycorpersium esculentum L. Int. J. Curr. Res. 2012, 4, 049-051.

24. Kashem, M.A.; Sarker, A.; Hossain, I.; Islam, M.S. Comparison of the effect of vermicompost and inorganic fertilizers on vegetative growth and fruit production of tomato (Solanum lycopersicum L.). Open J. Soil Sci. 2015, 5, 53. [CrossRef]

25. Yang, H.S.; Peng, T.W.; Madhavan, P.; Abdul, M.S.S.; Akowuah, G.A. Phytochemical Analysis and Antibacterial activity of Methanolic extract of Clinacanthus nutans Leaf. Int. J. Drug Dev. Res. 2013, 5, 349-355.

26. Zucco, M.A.; Walters, S.A.; Chong, S.-K.; Klubek, B.P.; Masabni, J.G. Effect of soil type and vermicompost applications on tomato growth. Int. J. Recycl. Org. Waste Agric. 2015, 4, 135-141. [CrossRef]

27. Cabanas-Echevarría, M.; Torres-García, A.; Díaz-Rodríguez, B.; Ardisana, E.F.H.; Creme-Ramos, Y. Influence of three bioproducts of organic origin on the production of two banana clones (Musa spp. AAB.) obtained by tissue cultures. Alimentaria 2005, 369, 111-116.

28. Acevedo, I.C.; Pire, R. Effects of vermicompost as substrate amendment on the growth of papaya (Carica papaya L.). Interciencia 2004, 29, 274-279.

29. Sardoei, A.S.; Roien, A.; Sadeghi, T.; Shahadadi, F.; Mokhtari, T.S. Effect of Vermicompost on the Growth and Flowering of African Marigold (Tagetes erecta). Am.-Euras. J. Agric. Environ. Sci. 2014, 14, 631-635.

30. Chattopadhyay, A. Effect of Vermiwash and Vermicompost on an Ornamental Flower, Zinnia sp. J. Hortic. 2014, 1, 112. [CrossRef]

31. Donald, D.G.M.; Visser, L.B. Vermicompost as a possible growth medium for the production of commercial forest nursery stock. Appl. Plant Sci. 1989, 3, 110-113.

32. Lazcano, C.; Sampedro, L.; Zas, R.; Domínguez, J. Vermicompost enhances germination of the maritime pine (Pinus pinaster Ait.). New For. 2010, 39, 387-400. [CrossRef]

33. Lazcano, C.; Sampedro, L.; Zas, R.; Domínguez, J. Assessment of plant growth promotion by vermicompost in different progenies of maritime pine (Pinus pinaster Ait.). Compost Sci. Util. 2010, 18, 111-118. [CrossRef] 
34. Solihah, M.; Wan Rosli, W.; Nurhanan, A. Phytochemicals screening and total phenolic content of Malaysian Zea mays hair extracts. Int. Food Res. J. 2012, 19, 1533-1538.

35. Giusti, M.M.; Wrolstad, R.E. Characterization and measurement of anthocyanins by UV-visible spectroscopy. In Current Protocols in Food Analytical Chemistry; John Wiley and Sons, Inc.: Hoboken, NJ, USA, 2001.

36. Sun, T.; Powers, J.R.; Tang, J. Effect of enzymatic macerate treatment on rutin content, antioxidant activity, yield, and physical properties of asparagus juice. J. Food Sci. 2007, 72, S267-S271. [CrossRef] [PubMed]

37. Lin, J.-Y.; Tang, C.-Y. Determination of total phenolic and flavonoid contents in selected fruits and vegetables, as well as their stimulatory effects on mouse splenocyte proliferation. Food Chem. 2007, 101, 140-147. [CrossRef]

38. Sulaiman, S.F.; Ooi, K.L. Polyphenolic and vitamin C contents and antioxidant activities of aqueous extracts from mature-green and ripe fruit fleshes of Mangifera sp. J. Agric. Food Chem. 2012, 60, 11832-11838. [CrossRef] [PubMed]

39. Shao, P.; Chen, X.; Sun, P. Chemical characterization, antioxidant and antitumor activity of sulfated polysaccharide from Sargassum horneri. Carbohydr. Polym. 2014, 105, 260-269. [CrossRef] [PubMed]

40. Abdul Rahim, M.H.; Zakaria, Z.A.; Mohd Sani, M.H.; Omar, M.H.; Yakob, Y.; Cheema, M.S.; Ching, S.M.; Ahmad, Z.; Abdul Kadir, A. Methanolic extract of Clinacanthus nutans exerts antinociceptive activity via the opioid/nitric oxide-mediated, but cGMP-independent, pathways. Evid.-Based Complement. Altern. Med. 2016, 2016, 1494981. [CrossRef] [PubMed]

41. Molyneux, P. The use of the stable free radical diphenylpicrylhydrazyl (DPPH) for estimating antioxidant activity. Songklanakarin J. Sci. Technol. 2004, 26, 211-219.

42. Almeida, M.M.B.; de Sousa, P.H.M.; Arriaga, Â.M.C.; do Prado, G.M.; de Carvalho Magalhães, C.E.; Maia, G.A.; de Lemos, T.L.G. Bioactive compounds and antioxidant activity of fresh exotic fruits from northeastern Brazil. Food Res. Int. 2011, 44, 2155-2159. [CrossRef]

43. Arnao, M.B. Some methodological problems in the determination of antioxidant activity using chromogen radicals: A practical case. Trends Food Sci. Technol. 2000, 11, 419-421. [CrossRef]

44. Prior, R.L.; Wu, X.; Schaich, K. Standardized methods for the determination of antioxidant capacity and phenolics in foods and dietary supplements. J. Agric. Food Chem. 2005, 53, 4290-4302. [CrossRef] [PubMed]

45. Bondet, V.; Brand-Williams, W.; Berset, C. Kinetics and mechanisms of antioxidant activity using the DPPH. free radical method. LWT-Food Sci. Technol. 1997, 30, 609-615. [CrossRef]

46. Kim, D.-O.; Lee, K.W.; Lee, H.J.; Lee, C.Y. Vitamin C equivalent antioxidant capacity (VCEAC) of phenolic phytochemicals. J. Agric. Food Chem. 2002, 50, 3713-3717. [CrossRef] [PubMed]

47. Coria-Cayupán, Y.S.; Sánchez de Pinto, M.A.I.; Nazareno, M.N.A. Variations in bioactive substance contents and crop yields of lettuce (Lactuca sativa L.) cultivated in soils with different fertilization treatments. J. Agric. Food Chem. 2009, 57, 10122-10129. [CrossRef] [PubMed]

48. Pant, A.; Radovich, T.J.K.; Hue, N.V.; Arancon, N.Q. Effects of vermicompost tea (aqueous extract) on pak choi yield, quality, and on soil biological properties. Compost Sci. Util. 2011, 19, 279-292. [CrossRef]

49. Luján-Hidalgo, M.C.; Pérez-Gómez, L.E.; Abud-Archila, M.; Meza-Gordillo, R.; Ruiz-Valdiviezo, V.M.; Dendooven, L.; Gutiérrez-Miceli, F.A. Growth, phenolic content and antioxidant activity in Chincuya (Annona purpurea Moc \& Sesse ex Dunal) cultivated with vermicompost and phosphate rock. Compost Sci. Util. 2015, 23, 276-283.

50. Ksouri, R.; Megdiche, W.; Debez, A.; Falleh, H.; Grignon, C.; Abdelly, C. Salinity effects on polyphenol content and antioxidant activities in leaves of the halophyte Cakile maritima. Plant Physiol. Biochem. 2007, 45, 244-249. [CrossRef] [PubMed]

51. Downey, P.J.; Levine, L.H.; Musgrave, M.E.; McKeon-Bennett, M.; Moane, S. Effect of hypergravity and phytohormones on isoflavonoid accumulation in soybean (Glycine max L.) callus. Micrograv. Sci. Technol. 2013, 25, 9-15. [CrossRef]

52. Adhikary, S. Vermicompost, the story of organic gold: A review. Agric. Sci. 2012, 3, 905. [CrossRef]

53. Moldovan, B.; Popa, A.; David, L. Effects of storage temperature on the total phenolic content of Cornelian Cherry (Cornus mas L.) fruits extracts. J. Appl. Bot. Food Qual. 2016, 89. [CrossRef]

54. Del-Toro-Sánchez, C.L.; Gutiérrez-Lomelí, M.; Lugo-Cervantes, E.; Zurita, F.; Robles-García, M.A.; Ruiz-Cruz, S.; Aguilar, J.A.; Rio, M.-D.; Alfredo, J.; Guerrero-Medina, P.J. Storage effect on phenols and on the antioxidant activity of extracts from Anemopsis californica and inhibition of elastase enzyme. J. Chem. 2015, 2015, 602136. [CrossRef] 
55. Ferrante, A.; Maggiore, T. Chlorophyll a fluorescence measurements to evaluate storage time and temperature of Valeriana leafy vegetables. Postharvest Biol. Technol. 2007, 45, 73-80. [CrossRef]

56. Varela-Santos, E.; Ochoa-Martinez, A.; Tabilo-Munizaga, G.; Reyes, J.E.; Pérez-Won, M.; Briones-Labarca, V.; Morales-Castro, J. Effect of high hydrostatic pressure (HHP) processing on physicochemical properties, bioactive compounds and shelf-life of pomegranate juice. Innov. Food Sci. Emerg. Technol. 2012, 13, 13-22. [CrossRef]

57. Serea, C.; Barna, O.; Manley, M.; Kidd, M. Effect of storage temperature on the ascorbic acid content, total phenolic content and antioxidant activity in lettuce (Lactuca sativa L.). J. Anim. Plant Sci. 2014, 24, 1173-1177.

58. Lee, C.Y.; Kagan, V.; Jaworski, A.W.; Brown, S.K. Enzymic browning in relation to phenolic compounds and polyphenoloxidase activity among various peach cultivars. J. Agric. Food Chem. 1990, 38, 99-101. [CrossRef]

59. Janovitz-Klapp, A.H.; Richard, F.C.; Goupy, P.M.; Nicolas, J.J. Kinetic studies on apple polyphenol oxidase. J. Agric. Food Chem. 1990, 38, 1437-1441. [CrossRef]

60. Kim, D.O.; Padilla-Zakour, O.I. Jam processing effect on phenolics and antioxidant capacity in anthocyanin-rich fruits: Cherry, plum, and raspberry. J. Food Sci. 2004, 69, S395-S400. [CrossRef]

61. He, J. Isolation of Anthocyanin Mixtures from Fruits and Vegetables and Evaluation of Their Stability, Availability and Biotransformation in the Gastrointestinal Tract. Ph.D. Thesis, The Ohio State University, Columbus, OH, USA, 2008.

62. Shen, W.; Nada, K.; Tachibana, S. Involvement of polyamines in the chilling tolerance of cucumber cultivars. Plant Physiol. 2000, 124, 431-440. [CrossRef] [PubMed]

63. Malik, A.; Holm, L.; Johansson, E. Soil and starter fertilizer and its effect on yield and protein composition of malting barley. J. Soil Sci. Plant Nutr. 2012, 12, 835-849. [CrossRef]

64. Trombley, J.D.; Loegel, T.N.; Danielson, N.D.; Hagerman, A.E. Capillary electrophoresis methods for the determination of covalent polyphenol-protein complexes. Anal. Bioanal. Chem. 2011, 401, 1523-1529. [CrossRef] [PubMed]

65. Le Bourvellec, C.; Renard, C. Interactions between polyphenols and macromolecules: Quantification methods and mechanisms. Crit. Rev. Food Sci. Nutr. 2012, 52, 213-248. [CrossRef] [PubMed]

66. Ozdal, T.; Capanoglu, E.; Altay, F. A review on protein-phenolic interactions and associated changes. Food Res. Int. 2013, 51, 954-970. [CrossRef]

Sample Availability: Samples of the compounds are not available from the authors.

(C) 2018 by the authors. Licensee MDPI, Basel, Switzerland. This article is an open access article distributed under the terms and conditions of the Creative Commons Attribution (CC BY) license (http://creativecommons.org/licenses/by/4.0/). 